\title{
Does Platelet-Rich Fibrin Decrease Dimensional Changes and Improve Postoperative Comfort in Post-Extraction Sockets? An Overview of Systematic Reviews
}

\author{
Vittorio Moraschini ${ }^{1}$ (D), Carlos Fernando de Almeida Barros Mourão ${ }^{2}$ (D), \\ Rafael Coutinho de Mello Machado ${ }^{2}$ (D), Jhonathan Raphaell Barros Nascimento ${ }^{2}$, Kayvon Javid ${ }^{2}$, \\ Monica Diuana Calasans-Maia ${ }^{3}$, Angelo Cardarelli ${ }^{4}$, Pietro Montemezzi ${ }^{5}$ and \\ Jose de Albuquerque Calasans-Maia 6,* ${ }^{1}$ \\ 1 Department of Research in Periodontics, School of Dentistry, Universidade Veiga de Almeida, \\ Rio de Janeiro 20271-020, Brazil; vitt.mf@gmail.com \\ 2 Postgraduate Program in Dentistry School, Universidade Federal Fluminense, Niterói, \\ Rio de Janeiro 24020-140, Brazil; mouraocf@gmail.com (C.F.d.A.B.M.); \\ rafaelcoutinhodemello@yahoo.com.br (R.C.d.M.M.); jhonathan_bn@hotmail.com (J.R.B.N.); \\ onecure@aol.com (K.J.) \\ 3 Department of Oral Surgery, School of Dentistry, Universidade Federal Fluminense, Niterói, \\ Rio de Janeiro 24220-900, Brazil; monicacalasans@id.uff.br \\ 4 Private Practice, 86170 Isernia, Italy; angelo_cardarelli@libero.it \\ 5 Private Practice, 24121 Bergamo, Italy; m.montemezzi@libero.it \\ 6 Department of Orthodontics, School of Dentistry, Universidade Federal Fluminense, Niterói, \\ Rio de Janeiro 24020-140, Brazil \\ * Correspondence: josecalasans@id.uff.br; Tel.: +55-21-981535874
}

Received: 22 June 2020; Accepted: 12 August 2020; Published: 20 August 2020

\begin{abstract}
This overview aimed to evaluate the methods, quality, and outcomes of systematic reviews (SRs) conducted to investigate the effects of platelet-rich fibrin (PRF) in dental sockets on promoting bone regeneration and soft tissue healing and diminishing the incidence of pain, swelling, trismus, and alveolar osteitis after tooth extraction. An electronic search without date or language restriction was done in PubMed/MEDLINE, Cochrane, and Web of Science until March 2020. Eligibility criteria included SRs that assessed the effect of PRF for human alveolar socket preservation. The quality assessment of the included studies was performed using AMSTAR 2 guidelines. The protocol of this overview was recorded in PROSPERO under the number CRD42018089617. The search and selection process yielded 13 studies published between 2011 and 2018. The analysis of the studies showed inconclusive data for the effect of the PRF and the dimensional changes. There is no definitive evidence for the impact of using PRF alone on bone regeneration in post-extraction sockets. The use of PRF improves soft tissue healing and reduces pain, bleeding, and osteitis in post-extraction sockets.
\end{abstract}

Keywords: alveolar socket preservation; platelet-rich fibrin; PRF; growth factors; tooth extraction

\section{Introduction}

Tooth extraction is the most frequent practice in oral surgery and is associated with critical physiologic alterations to the alveolar process [1], which may strictly affect alveolar bone architecture [2] The most significant postoperative symptoms affecting soft and hard tissues and patient comfort are pain, bleeding, trismus, swelling, delayed healing, and infection. The principal postoperative symptom that affects hard tissue is the progressive process of bone resorption, which is more severe in 
the horizontal width than in the vertical height. The majority of the resorption process occurs during the first six months of the post-extraction period, but it continues throughout the rest of the patient's life $[3,4]$.

There are many different approaches for bone regeneration, such as mesenchymal stem cells, nano biomaterials, Bone Morphogenetic Proteins (BMPs), and some bioactive molecules like melatonin and simvastatin.

The role of mesenchymal stem cells [5], oral-derived stem cells [6], and dental-derived mesenchymal stem cells [7] have been reported for bone regeneration with the potential to significantly influence bone and periodontal treatment in the future.

Nanostructured calcium phosphates have been extensively used in dentistry and medicine as a bone substitute. With an excellent biocompatibility and osteoconductivity, nanomaterials have been widely investigated for their application in the field of bone tissue engineering because of their dimensional similarity to human bone tissue. In addition, nanostructured biomaterials have an increased surface area and roughness, aiding in the adsorption of neighboring proteins and cells and acting as a carrier for drug delivery system [8].

Platelet-rich fibrin (PRF) is a second generation of the platelet concentrate with the presence of platelets and leukocytes in a dense fibrin matrix that does not necessitate an activator before use. It is prepared from non-anticoagulated blood undergoing single centrifugation $[9,10]$. As it is a reservoir of platelets, leukocytes, cytokines, and immune cells, PRF was reported to permit the slow release of cytokines (transforming growth factor, platelet-derived growth factor, vascular endothelial growth factor, and epidermal growth factor), which play a critical role in angiogenesis, tissue healing, and cicatrization [10-13]. Previous systematic reviews (SRs) suggested that positive and favorable effects of PRF exist in dental sockets on promoting bone regeneration $[1,2,9,14-17]$ and soft tissue healing $[1,14,18,19]$, although another SR [20] showed no beneficial role in bone healing after tooth extraction. Notwithstanding previous SRs suggesting that the local application of PRF after a tooth extraction is a suitable method for reducing pain, swelling, and the incidence of alveolar osteitis $[1,14,17,18,20]$, the benefit of autologous platelet concentrate on decreasing pain in extraction sockets is still not measurable. In addition, PRF should be recommended for local application into the sockets for patients undertaking complicated surgical extraction [17]. This overview aimed to evaluate the methods, quality, and outcomes of systematic reviews (SRs) conducted to evaluate the effects of platelet-rich fibrin (PRF) in dental sockets on promoting bone regeneration and soft tissue healing and reducing the incidence of pain, swelling, trismus, and alveolar osteitis after tooth extraction.

\section{Materials and Methods}

\subsection{Protocol Registration}

The protocol of this overview was registered in PROSPERO under the number CDR42018116302. There was no deviation from the initially specified protocol as registered. Although not an SR, the present study's basic methodology followed the PRISMA checklist [21].

\subsubsection{Focused Question: PICO Criteria [22]}

Does the usage of PRF (I) decrease dimensional changes and improve soft tissue epithelization and postoperative comfort $(\mathrm{O})$ in post-extraction sockets $(\mathrm{P})$ when compared to spontaneous healing $(\mathrm{C})$ ?

\subsubsection{Outcome Measures}

The primary outcome variable was to evaluate the clinical effect of PRF to reduce the dimensional changes in alveolar socket preservation. The secondary outcome variables were to assess the PRF's clinical effect in soft tissue healing, postoperative pain, swelling, bleeding, and osteitis. 


\subsection{Search Strategy}

An electronic search without date or language limitation was conducted in PubMed/MEDLINE, Scopus, Web of Science, and Cochrane Library until March 2020. Furthermore, a manual search was performed of the following journals: Journal of Periodontology, Journal of Clinical Periodontology, Clinical Oral Implants Research, Clinical Implant Dentistry and Related Research, The International Journal of Oral \& Maxillofacial Implants, International Journal of Oral \& Maxillofacial Surgery, and Journal of Cranio-Maxillo-Facial Surgery. A search of the Grey Literature Report (http//:www.greylit.org) and OpenGrey databases (http//:www.opengrey.eu) revealed unpublished studies (grey literature). Searches in references of the included studies (cross-referencing) were also conducted. MeSH terms, keywords, and other free terms related to "platelet-rich-fibrin", "PRF", "autologous platelet concentrate", "tooth extraction", "mandibular third molar", "mandibular third molar extraction", "post-extraction sockets", "post-extraction socket healing", "alveolar socket preservation", "alveolar ridge preservation", "regenerative dentistry", and "systematic review" were used with Boolean operators (OR, AND) to combine searches. The search strategy included appropriate changes in the keywords and followed the syntactic rules of each database.

\subsection{Eligibility Criteria}

\subsubsection{Inclusion Criteria}

SRs with or without meta-analysis evaluating the effect of PRF alone for alveolar socket preservation in humans.

\subsubsection{Exclusion Criteria}

SRs that included only studies with other types of platelet concentrates (e.g., platelet-rich plasma), narrative reviews, or SRs from in vitro or animal studies.

\subsection{Screening Process}

The search and selection process were done by two independent reviewing authors (V.M and M.D.C-M) starting with evaluation of titles and abstracts. Next, full papers were selected for careful reading and considered according to the inclusion/exclusion criteria for posterior data extraction. Divergences between reviewing authors were resolved through careful discussion. When necessary, the authors of the included studies were emailed for the elucidation of persisting doubts.

\subsection{Data Extraction}

Once presented, the following data were extracted from the included studies by two independent reviewing authors (C.F.M. and R.C.): authors, focused questions, number of included studies, outcome measures, meta-analysis results, number of sockets evaluated, the methodology for PRF preparation, AMSTAR 2 score, and comments.

\subsection{Quality Assessment of the Systematic Reviews}

The quality assessment of the SRs was carried out by two authors (C.F.A.B.M. and R.C.M.M.). The quality of the methodology of each included SR was assessed with the AMSTAR 2 [23]. The guidelines report 16 items that are classified into 4 options: 1 indicates "yes," 2 indicates "no," 3 indicates "cannot answer", and 4 indicates "not applicable". Only items with option 1 ("yes") generated scores. Therefore, each article could obtain a score between 0 (no criteria) and 16 (all criteria). 


\subsection{Statistical Analysis}

The extracted data were pooled and analyzed qualitatively and quantitatively (variation, mean, and standard deviation) through descriptive statistics. For descriptive analysis, the Prism software (version 7.0d, GraphPad Software, La Jolla, CA, USA) was used.

\section{Results}

\subsection{Literature Search}

The initial search resulted in 42 titles on MEDLINE/PubMed, 42 titles on Scopus, 21 on Web of Science, and none on Cochrane Library. After critical reading, 13 studies [1,2,9,14-20,24-26] published between 2011 and 2018 were included in the current overview. All full-text articles assessed for eligibility were included in this overview $(n=13)$. A search of grey literature did not result in any additional studies. The process of searching for and selecting articles can be followed in Figure 1.

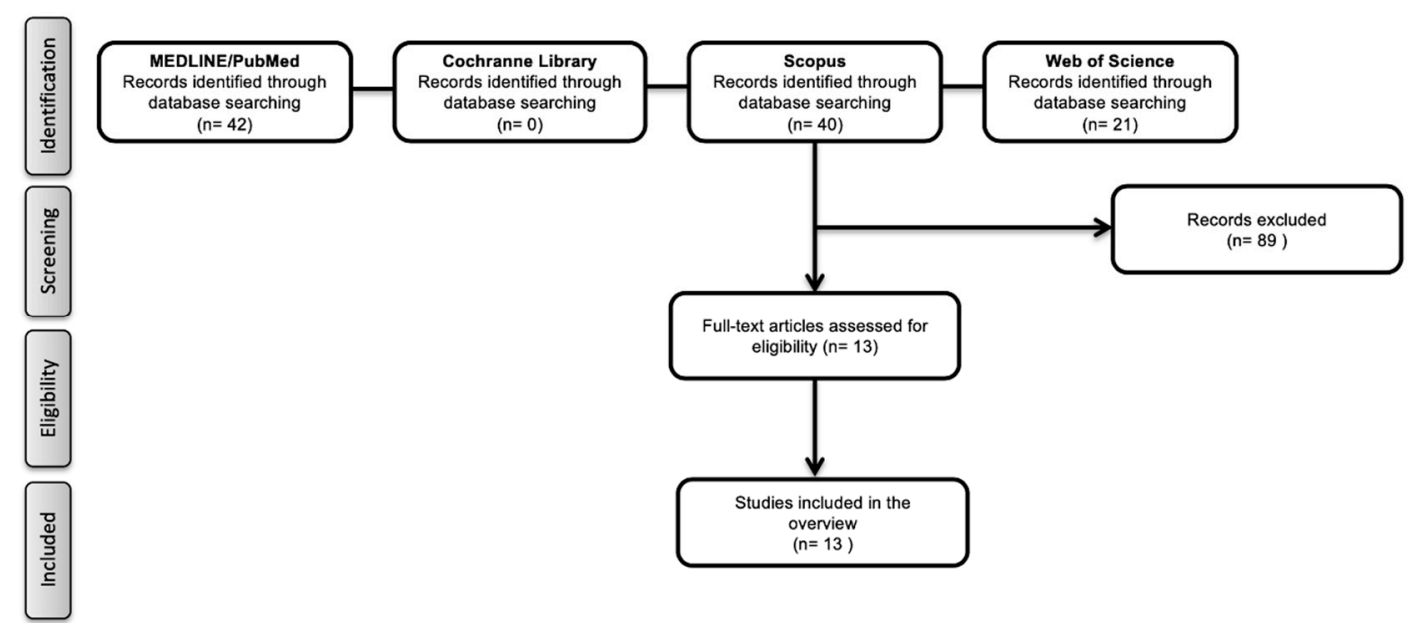

Figure 1. Flow diagram (PRISMA format) of the screening and selection process.

\subsection{Study Characteristics}

The characteristics of the included studies are presented in Table 1. The SRs included randomized clinical trials (RCTs) $[1,2,9,14-20,24-26]$, controlled clinical trials $[1,18,20,24,26]$, and retrospective studies $[17,19]$. The number of included studies in each SR ranged from $1[2,9,25]$ to 16 [15]. SRs included twenty-six different studies. The studies evaluated a total of 4463 sockets preserved with PRF. SRs reported different methodologies for the production of PRF membranes. Three SRs $[19,25,26]$ did not report the PRF production methodology used by the studies. 
Table 1. Main characteristics of included studies.

\begin{tabular}{|c|c|c|c|c|c|}
\hline Authors & Focused Question & $\begin{array}{l}\text { No. of Included Studies } \\
\text { Design of Studies (No.) }\end{array}$ & Outcome Measures & Meta-Analysis Results & No. of Sockets Evaluated \\
\hline Al-Hamed et al., 2017 & $\begin{array}{l}\text { Is platelet-rich fibrin effective } \\
\text { after mandibular third molar } \\
\text { extraction? }\end{array}$ & $\begin{array}{c}6 \\
\text { RCT (SM)-4 } \\
\text { RCT (P)-1 } \\
\text { CC }-1 \\
\end{array}$ & $\begin{array}{l}\text { Pain and analgesic consumption, } \\
\text { swelling, trismus, alveolar } \\
\text { osteitis, periodontal pocket depth, } \\
\text { bone healing, soft tissue healing }\end{array}$ & $\begin{array}{c}\text { Bone regeneration: MD } 1.43 \text { (95\% CI }-0.5 \text { to } \\
0.49), p=0.98 \\
\text { (The use of PRF did not significantly affect } \\
\text { the bone regeneration) }\end{array}$ & 335 \\
\hline Annunziata et al., 2018 & $\begin{array}{l}\text { What is the effect of platelet } \\
\text { concentrates on alveolar } \\
\text { socket preservation compared } \\
\text { with spontaneous alveolar socket } \\
\text { healing }\end{array}$ & $\begin{array}{l}4 \\
\text { RCT (SM)-3 } \\
\text { RCT (P)-1 }\end{array}$ & $\begin{array}{l}\text { Qualitative and/or quantitative } \\
\text { changes of soft and hard tissues. }\end{array}$ & $\mathrm{NP}$ & 189 \\
\hline Canellas et al., 2019 & $\begin{array}{c}\text { What indications has PRF shown } \\
\text { to be effective in oral surgical } \\
\text { procedures? }\end{array}$ & $\begin{array}{c}16 \\
\text { RCT (SM)-11 } \\
\text { RCT (P)-5 }\end{array}$ & $\begin{array}{l}\text { Bone healing, soft tissue healing, } \\
\text { bone density and alveolar } \\
\text { dimensions }\end{array}$ & $\begin{array}{c}\text { Alveolar osteitis: OR } 0.33 \text { ( } 95 \% \text { CI } 0.14 \text { to } \\
0.76), p=0.009 \\
\text { (The use of PRF significantly decreases the } \\
\text { occurrence of osteitis) }\end{array}$ & 810 \\
\hline Castro et al., 2017 & $\begin{array}{c}\text { Does L-PRF promote } \\
\text { regeneration in systemically } \\
\text { healthy patients (ASA I) during } \\
\text { guided bone regeneration } \\
\text { techniques and implant surgery } \\
\text { compared to traditional } \\
\text { techniques? }\end{array}$ & $\begin{array}{c}7 \\
\operatorname{RCT}(\mathrm{SM})-4 \\
\operatorname{RCT}(\mathrm{P})-3\end{array}$ & $\begin{array}{l}\text { Bone healing, } \\
\text { soft tissue healing, pain }\end{array}$ & $\mathrm{NP}$ & 227 \\
\hline Del Fabbro et al., 2014 & $\begin{array}{l}\text { In patients undergoing tooth } \\
\text { extraction, does the local } \\
\text { application of autologous platelet } \\
\text { concentrate improve clinical, } \\
\text { radiographic, and histological } \\
\text { outcomes related to socket } \\
\text { healing as compared to control? }\end{array}$ & $\begin{array}{c}1 \\
\mathrm{RCT}(\mathrm{SM})\end{array}$ & Bone healing & $\begin{array}{c}\text { Alveolar bone regeneration: MD } 20.4 \text { (95\% } \\
\text { CI } 13.2 \text { to } 27.5), p<0.00001 \\
\text { (The use of PRF significantly affects the } \\
\text { alveolar bone regeneration) }\end{array}$ & 44 \\
\hline Del Fabbro et al., 2011 & $\begin{array}{l}\text { Is autologous platelet concentrate } \\
\text { beneficial for post-extraction } \\
\text { socket healing? }\end{array}$ & $\begin{array}{c}1 \\
\mathrm{RCT}(\mathrm{SM})-1\end{array}$ & Bone healing & NP & 40 \\
\hline
\end{tabular}


Table 1. Cont

\begin{tabular}{|c|c|c|c|c|c|}
\hline Authors & Focused Question & $\begin{array}{l}\text { No. of Included Studies } \\
\text { Design of Studies (No.) }\end{array}$ & Outcome Measures & Meta-Analysis Results & No. of Sockets Evaluated \\
\hline Del Fabbro et al., 2017 & $\begin{array}{l}\text { Does the adjunct of autologous } \\
\text { platelet concentrates produce } \\
\text { benefits to post-extraction socket } \\
\text { healing for hard and soft tissue } \\
\text { parameters, postoperative } \\
\text { complications, and patient's } \\
\text { postoperative quality of life? }\end{array}$ & $\begin{array}{l}12 \\
\text { RCT (SM)—9 } \\
\text { RCT (P)—2 } \\
\text { CCT-1 }\end{array}$ & $\begin{array}{l}\text { Complications and } \\
\text { adverse events, discomfort, } \\
\text { quality of life, bone healing, } \\
\text { soft tissue healing }\end{array}$ & $\begin{array}{c}\text { Soft tissue healing: MD-1.63 (95\% CI -2.05 } \\
\text { to 1.22), } p<0.00001 \\
\text { (The use of PRF significantly increases the } \\
\text { alveolar soft tissue healing) } \\
\text { Probing depth: MD 20.4 (95\% CI 13.2 to 27.5), } \\
p<0.00001 \\
\text { (The use of PRF significantly decreases the } \\
\text { probing depth) } \\
\text { Inflammation/infection: MD } 0.27 \text { ( } 95 \% \text { CI } \\
0.06 \text { to } 1.27), p=0.10 \\
\text { (The use of PRF did not significantly affect } \\
\text { the alveolar inflammation or infection) } \\
\text { Alveolar bone regeneration: MD-1.58 (95\% } \\
\text { CI - } 2.83 \text { to - } 0.32 \text { ), } p=0.01 \\
\text { (The use of PRF significantly affects the } \\
\text { alveolar bone regeneration) }\end{array}$ & 712 \\
\hline He et al., 2017 & $\begin{array}{l}\text { Is the application of platelet-rich } \\
\text { fibrin (PRF) during tooth } \\
\text { extraction able to accelerate } \\
\text { wound healing, stimulate osseous } \\
\text { and soft tissue regeneration, and } \\
\text { reduce unwanted side effects? }\end{array}$ & $\begin{array}{c}10 \\
\text { RCT (SM)—-7 } \\
\text { RCT (P)-2 } \\
\text { Retrospective-1 }\end{array}$ & $\begin{array}{c}\text { Pain, swelling, } \\
\text { trismus, alveolar osteitis, } \\
\text { osteoblastic } \\
\text { activity }\end{array}$ & $\begin{array}{c}\text { Pain: MD-1.58 (95\% CI }-2.83 \text { to }-0.32, \\
p=0.01 \\
\text { (The use of PRF significantly relieves } \\
\text { the pain) } \\
\text { 1-day postoperative swelling: MD-0.46 } \\
\text { (95\% CI }-1.03 \text { to } 0.10), p=0.11 \\
\text { (The use of PRF did not significantly affect } \\
\text { the 1-day postoperative swelling) } \\
\text { Trismus: MD-4.33 (95\% CI - } 10.9 \text { to } 2.29 \text { ), } \\
p=0.20 \\
\text { (The use of PRF did not significantly affect } \\
\text { the trismus) } \\
\text { Alveolar osteitis: OR } 0.22 \text { ( } 95 \% \text { CI } 0.10 \text { to } \\
0.46 \text { ), } p<0.0001 \\
\text { (The use of PRF significantly decreases the } \\
\text { occurrence of alveolar osteitis) } \\
\text { Osteoblastic activity: MD } 0.03 \text { ( } 95 \% \text { CI }-0.46 \\
\text { to } 0.53), p=0.90 \\
\text { (The use of PRF did not significantly affect } \\
\text { osteoblastic activity }\end{array}$ & 935 \\
\hline
\end{tabular}


Table 1. Cont.

\begin{tabular}{|c|c|c|c|c|c|}
\hline Authors & Focused Question & $\begin{array}{l}\text { No. of Included Studies } \\
\text { Design of Studies (No.) }\end{array}$ & Outcome Measures & Meta-Analysis Results & No. of Sockets Evaluated \\
\hline Miron et al., 2017 & $\begin{array}{c}\text { Has platelet rich fibrin (PRF) been } \\
\text { shown effective for } \\
\text { tissue repair/regeneration of } \\
\text { either soft or hard tissues in } \\
\text { dentistry? }\end{array}$ & $\begin{array}{c}4 \\
\text { RCT (SM)-2 } \\
\text { RCT (P)-1 } \\
\text { Retrospective-1 }\end{array}$ & Bone healing & NP & 501 \\
\hline $\begin{array}{l}\text { Moraschini and Barboza, } \\
2015\end{array}$ & $\begin{array}{l}\text { What is the effect of autologous } \\
\text { platelet concentrates for alveolar } \\
\text { socket preservation using } \\
\text { autologous plasma concentrates } \\
\text { when compared with natural } \\
\text { (spontaneous) socket healing? }\end{array}$ & $\begin{array}{c}2 \\
\text { RCT (P)-1 } \\
\text { CCT-1 }\end{array}$ & $\begin{array}{l}\text { Soft tissue healing, bone healing, } \\
\text { pain }\end{array}$ & NP & 37 \\
\hline Niu et al., 2018 & $\begin{array}{l}\text { Are platelet concentrates effective } \\
\text { for alveolar ridge preservation? }\end{array}$ & $\begin{array}{c}1 \\
\text { RCT }(\mathrm{P})-1\end{array}$ & Soft tissue healing, bone healing & $\mathrm{NP}$ & 44 \\
\hline Balli et al., 2018 & $\begin{array}{l}\text { Is leukocyte-platelet-rich fibrin } \\
\text { effective for ridge preservation } \\
\text { procedures after tooth } \\
\text { extractions? }\end{array}$ & $\begin{array}{c}2 \\
\text { RCT (SM)-1 } \\
\text { CCT-1 }\end{array}$ & Bone healing & NP & 104 \\
\hline Authors & Methodology for PRF Production & $\begin{array}{l}\text { AMSTAR } 2 \text { Score }(16 \\
\text { Items) }\end{array}$ & \multicolumn{3}{|c|}{ Comments } \\
\hline Annunziata et al., 2018 & $\begin{array}{l}3000 \mathrm{rpm} ; 10 \mathrm{~min} \text { (1 author) } \\
2700 \mathrm{rpm} ; 12 \mathrm{~min} \text { (3 authors) }\end{array}$ & 14 & \multicolumn{3}{|c|}{$\begin{array}{c}\text { There is growing evidence that platelet concentrates may be advantageously used in post-extraction sites, mainly } \\
\text { to improve soft tissue healing and to reduce postoperative symptoms }\end{array}$} \\
\hline Canellas et al., 2017 & $\begin{array}{c}3000 \mathrm{rpm} ; 10 \mathrm{~min} \\
2030 \mathrm{rpm} ; 10 \mathrm{~min} \text { (1 author) }\end{array}$ & 16 & \multicolumn{3}{|c|}{$\begin{array}{l}\text { The use of PRF in mandibular third molar surgery is an alternative method to decrease postoperative pain, } \\
\text { swelling, and reduce the risk of alveolar osteitis }\end{array}$} \\
\hline Canellas et al., 2019 & $\begin{array}{c}3000 \mathrm{rpm} ; 10 \mathrm{~min} \\
2700 \mathrm{rpm} ; 12 \mathrm{~min} \text { ( } 3 \text { authors) } \\
2030 \mathrm{rpm} ; 10 \mathrm{~min} \text { ( } 1 \text { author) }\end{array}$ & 15 & \multicolumn{3}{|c|}{$\begin{array}{l}\text { The available literature suggests that PRF has a positive effect on improving alveolar preservation in extraction } \\
\text { sockets }\end{array}$} \\
\hline Castro et al., 2017 & $\begin{array}{c}400 \mathrm{~g} / 10 \mathrm{~min} \text { (1 author) } \\
3000 \mathrm{rpm} ; 10 \mathrm{~min} \text { (4 authors) } \\
2700 \mathrm{rpm} ; 12 \mathrm{~min} \text { ( } 2 \text { authors) }\end{array}$ & 12 & \multicolumn{3}{|c|}{ PRF might have a positive effect on alveolar regeneration } \\
\hline Del Fabbro et al., 2014 & $1 \times ; 360-400 \mathrm{rpm} ; 20 \mathrm{~min}$ & 15 & \multicolumn{3}{|c|}{ There is a positive effect of platelet concentrates on bone formation in post-extraction sockets } \\
\hline Del Fabbro et al., 2011 & $1 \times ; 400 \mathrm{~g}(2030 \mathrm{rpm}) ; 10 \mathrm{~min}$ & 14 & \multicolumn{3}{|c|}{$\begin{array}{l}\text { Based on the reports of the selected studies, the use of platelet concentrates may be beneficial for reducing } \\
\text { postoperative pain and inflammation }\end{array}$} \\
\hline
\end{tabular}


Table 1. Cont

\begin{tabular}{|c|c|c|c|c|}
\hline Authors & Focused Question & $\begin{array}{l}\text { No. of Included Studies } \\
\text { Design of Studies (No.) }\end{array}$ & Outcome Measures & No. of Sockets Evaluated \\
\hline Del Fabbro et al., 2017 & $\begin{array}{c}1 \times: 360-400 \mathrm{rpm} \\
1 \times: \text { NR } \\
1 \times: 3000 \mathrm{rpm}(7 \text { authors }) \\
1 \times: 2700 \mathrm{rpm}(2 \text { authors }) \\
1 \times: 2030 \mathrm{rpm}(1 \text { author })\end{array}$ & 13 & \multicolumn{2}{|c|}{$\begin{array}{l}\text { PRF should be used in post-extraction sites to improve clinical and radiographic outcomes } \\
\text { such as bone density and soft tissue healing and postoperative symptoms }\end{array}$} \\
\hline He et al., 2017 & $\begin{array}{l}3000 \mathrm{rpm}: 10 \min \text { (7 authors) } \\
2030 \mathrm{rpm}: 10 \mathrm{~min} \text { (1 author) } \\
2700 \mathrm{rpm}: 10-12 \min \text { ( } 2 \text { authors) }\end{array}$ & 14 & \multicolumn{2}{|c|}{$\begin{array}{l}\text { Local application of PRF after lower third molar extraction is a valid method for relieving } \\
\text { pain and 3-day postoperative swelling and reducing the incidence of alveolar osteitis }\end{array}$} \\
\hline Miron et al., 2017 & NR & 9 & PRF was shown to ir & generation and limit dimensional changes post-extraction \\
\hline $\begin{array}{l}\text { Moraschini and Barboza, } \\
2015\end{array}$ & $\begin{array}{l}1 \times: 3000 \mathrm{rpm} \times 10 \mathrm{~min} \\
1 \times: 2700 \mathrm{rpm} \times 12 \mathrm{~min}\end{array}$ & 4 & The use of plasma concentr & $\begin{array}{l}\text { lerate healing and soft tissue epithelialization in extraction sockets } \\
\text { ostoperative pain and discomfort }\end{array}$ \\
\hline Niu et al., 2018 & NR & 13 & & $\begin{array}{l}\text { ht have a more positive effect } \\
\text { width and height preservation } \\
\text { does platelet-rich plasma }\end{array}$ \\
\hline Balli et al., 2018 & NR & 14 & The PRF & e horizontal and vertical crestal bone resorption \\
\hline
\end{tabular}

OR, odds ratio; MD, mean difference; NP, not performed; NR, not reported; PRF, platelet-rich fibrin; RCT (SM), randomized clinical trial split mouth; RCT (P), randomized clinical trial parallel group; CCT, controlled clinical trial; RPM, rotation per minute; min, minutes. 


\subsection{Findings Based on Previous Focused Questions}

\subsubsection{Primary Outcome Measures}

The effect of PRF on bone regeneration was assessed quantitatively through meta-analysis in three SRs $[1,9,20]$. In a study by Al-Hamed et al. [16], the use of PRF did not significantly affect bone regeneration $(p=0.98)$. In contrast in the SRs of Del Fabbro et al., 2014 [9] and Del Fabbro et al., 2017 [1], the use of PRF significantly affected the bone regeneration $(p<0.00001$ and $p=0.01$, respectively). The osteoblast activity was evaluated through meta-analysis by one SR [17]. The use of PRF did not significantly influence osteoblast activity $(p=0.90)$.

Five SRs [15,16,24-26] observed good performance of the PRF qualitatively in decreasing vertical and horizontal changes.

\subsubsection{Secondary Outcome Measures}

- Soft tissue healing

Six SRs [1,15-19] reported a favorable effect on the enhancement of the soft tissue healing and epithelization in the first weeks after extraction.

- Pain

One SR [17] evaluated the pain parameter through meta-analysis. The use of PRF significantly relieved pain $(p=0.01)$. Six SRs $[1,14,16-18,20]$ evaluated qualitatively the pain outcome. Five studies $[14,16-18,20]$ observed a lower incidence of pain or consumption of analgesic medication for patients with sockets preserved with PRF.

- $\quad$ Swelling

Three SRs $[14,17,20]$ evaluated the swelling parameter. In all, there was a favored effect for the use of PRF.

\section{- Osteitis}

Three SRs $[14,17,20]$ evaluated the effect of PRF on alveolar osteitis through meta-analysis. In all, the use of PRF significantly decreased the occurrence of osteitis after the extractions $(p=0.01, p=0.009$, and $p<0.0001$, respectively).

\section{- $\quad$ Trismus}

One SR [17] evaluated the effect of PRF on trismus through meta-analysis. The use of PRF did not significantly affect the trismus $(p=0.20)$. Another SR [16] reported a qualitatively positive effect of PRF on trismus.

\subsection{Quality Assessment}

Only one SR [14] fulfilled all the AMSTAR 2 scale requirements, showing a low risk of bias and high power of evidence (Table 2). The score varied from 9 [19] to 16 [14] points, with an average of $13.3 \pm 1.66(81 \%)$ out of a possible total of 16 points. Items $2,3,6,12$, and 16 were scored as positive for all included reviews. However, a high number of studies did not score items 4 and 5 . 
Table 2. Quality assessment checklist for systematic reviews (AMSTAR 2).

\begin{tabular}{|c|c|c|c|c|c|c|}
\hline $\begin{array}{l}\text { AMSTAR } \\
\text { Questions }\end{array}$ & $\begin{array}{l}\text { Al-hamed et al., } \\
2017\end{array}$ & $\begin{array}{c}\text { Canellas et al., } \\
2019\end{array}$ & $\begin{array}{c}\text { Castro et al., } \\
\quad 2017\end{array}$ & $\begin{array}{l}\text { Del Fabbro et al., } \\
2014\end{array}$ & $\begin{array}{l}\text { Del Fabbro et al., } \\
2011\end{array}$ & $\begin{array}{c}\text { Del Fabbro et al., } \\
2017\end{array}$ \\
\hline (1) Was an "a priori" design provided? & no & yes & yes & yes & no & yes \\
\hline $\begin{array}{l}\text { (2) Was there duplicate study selection and } \\
\text { data extraction? }\end{array}$ & yes & yes & yes & yes & Yes & yes \\
\hline (3) Was a comprehensive literature search performed? & yes & yes & yes & yes & yes & yes \\
\hline $\begin{array}{l}\text { (4) Was the status of publication (i.e., grey literature) } \\
\text { used as an inclusion criterion? }\end{array}$ & no & yes & no & yes & yes & no \\
\hline $\begin{array}{l}\text { (5) Was a list of studies (included and } \\
\text { excluded) provided? }\end{array}$ & yes & yes & no & no & no & no \\
\hline $\begin{array}{l}\text { (6) Were the characteristics of the included } \\
\text { studies provided? }\end{array}$ & yes & yes & yes & yes & yes & yes \\
\hline $\begin{array}{l}\text { (7) Was the scientific quality of the included studies } \\
\text { assessed and documented? }\end{array}$ & yes & yes & yes & yes & yes & yes \\
\hline $\begin{array}{l}\text { (8) Was the scientific quality of the included studies } \\
\text { used appropriately in formulating conclusions? }\end{array}$ & yes & yes & yes & yes & yes & no \\
\hline $\begin{array}{l}\text { (9) Were the methods used to combine the findings of } \\
\text { studies appropriate? }\end{array}$ & yes & no & no & yes & yes & yes \\
\hline (10) Was the likelihood of publication bias assessed? & yes & yes & yes & yes & yes & yes \\
\hline (11) Was the conflict of interest stated? & yes & no & yes & yes & yes & yes \\
\hline $\begin{array}{l}\text { (12) Did the review authors provide a satisfactory } \\
\text { explanation for, and discussion of, any heterogeneity } \\
\text { observed in the results of the review? }\end{array}$ & yes & yes & yes & yes & yes & yes \\
\hline $\begin{array}{l}\text { (13) Did the review authors account for RoB in } \\
\text { individual studies when interpreting/discussing the } \\
\text { results of the review? }\end{array}$ & yes & yes & yes & yes & yes & yes \\
\hline $\begin{array}{l}\text { (14) If meta-analysis was performed, did the review } \\
\text { authors assess the potential impact of RoB in } \\
\text { individual studies on the results of the meta-analysis } \\
\text { or other evidence synthesis? }\end{array}$ & yes & yes & $\mathrm{NP}$ & yes & $\mathrm{NP}$ & yes \\
\hline $\begin{array}{l}\text { (15) If meta-analysis was justified, did the review } \\
\text { authors use appropriate methods for statistical } \\
\text { combination of results? }\end{array}$ & no & yes & $\mathrm{NP}$ & yes & $\mathrm{NP}$ & yes \\
\hline
\end{tabular}


Table 2. Cont

\begin{tabular}{|c|c|c|c|c|c|c|c|}
\hline $\begin{array}{l}\text { AMSTAR } \\
\text { Questions }\end{array}$ & $\begin{array}{l}\text { Al-hamed et al., } \\
2017\end{array}$ & $\begin{array}{l}\text { Canellas et al., } \\
2019\end{array}$ & $\begin{array}{l}\text { Castro et al., } \\
\quad 2017\end{array}$ & $\begin{array}{l}\text { Del Fabbro et al., } \\
2014\end{array}$ & $\begin{array}{l}\text { Del Fabbro et al., } \\
2011\end{array}$ & \multicolumn{2}{|c|}{$\begin{array}{l}\text { Del Fabbro et al., } \\
2017\end{array}$} \\
\hline $\begin{array}{l}\text { technique for assessing the risk of bias in individual } \\
\text { studies that were included in the review? }\end{array}$ & yes & yes & yes & yes & yes & \multicolumn{2}{|l|}{ yes } \\
\hline Total (yes) & 13 & 14 & 12 & 15 & 13 & \multicolumn{2}{|l|}{13} \\
\hline $\begin{array}{c}\text { AMSTAR } \\
\text { Questions (cont) }\end{array}$ & He et al., 2017 & $\begin{array}{l}\text { Canellas } \\
\text { et al., } 2017\end{array}$ & $\begin{array}{l}\text { Miron } \\
\text { et al., } 2017\end{array}$ & $\begin{array}{l}\text { Moraschini and } \\
\text { Barboza, } 2015\end{array}$ & Niu et al., 2018 & $\begin{array}{l}\text { Annunziata et al., } \\
2018\end{array}$ & $\begin{array}{l}\text { Balli et al., } \\
2018\end{array}$ \\
\hline (1) Was an "a priori" design provided? & no & yes & yes & yes & yes & yes & yes \\
\hline $\begin{array}{l}\text { (2) Was there duplicate study selection and } \\
\text { data extraction? }\end{array}$ & yes & yes & yes & yes & yes & yes & yes \\
\hline (3) Was a comprehensive literature search performed? & yes & yes & yes & yes & yes & yes & yes \\
\hline $\begin{array}{l}\text { (4) Was the status of publication (i.e., grey literature) } \\
\text { used as an inclusion criterion? }\end{array}$ & no & yes & no & no & no & yes & no \\
\hline $\begin{array}{l}\text { (5) Was a list of studies (included and } \\
\text { excluded) provided? }\end{array}$ & yes & yes & no & yes & yes & yes & yes \\
\hline $\begin{array}{l}\text { (6) Were the characteristics of the included } \\
\text { studies provided? }\end{array}$ & yes & yes & yes & yes & yes & yes & yes \\
\hline $\begin{array}{l}\text { (7) Was the scientific quality of the included studies } \\
\text { assessed and documented? }\end{array}$ & yes & yes & no & Yes & yes & yes & yes \\
\hline $\begin{array}{l}\text { (8) Was the scientific quality of the included studies } \\
\text { used appropriately in formulating conclusions? }\end{array}$ & yes & yes & no & yes & no & yes & yes \\
\hline $\begin{array}{l}\text { (9) Were the methods used to combine the findings of } \\
\text { studies appropriate? }\end{array}$ & yes & yes & yes & yes & yes & no & yes \\
\hline (10) Was the likelihood of publication bias assessed? & yes & yes & no & yes & yes & yes & yes \\
\hline (11) Was the conflict of interest stated? & yes & yes & yes & yes & yes & yes & yes \\
\hline $\begin{array}{l}\text { (12) Did the review authors provide a satisfactory } \\
\text { explanation for, and discussion of, any heterogeneity } \\
\text { observed in the results of the review? }\end{array}$ & yes & yes & yes & yes & yes & yes & yes \\
\hline
\end{tabular}


Table 2. Cont

\begin{tabular}{|c|c|c|c|c|c|c|c|}
\hline $\begin{array}{l}\text { AMSTAR } \\
\text { Questions }\end{array}$ & $\begin{array}{l}\text { Al-hamed et al., } \\
2017\end{array}$ & $\begin{array}{l}\text { Canellas et al., } \\
\quad 2019\end{array}$ & $\begin{array}{l}\text { Castro et al., } \\
\quad 2017\end{array}$ & $\begin{array}{l}\text { Del Fabbro et al., } \\
2014\end{array}$ & $\begin{array}{l}\text { Del Fabbro et al., } \\
2011\end{array}$ & \multicolumn{2}{|c|}{$\begin{array}{l}\text { Del Fabbro et al., } \\
2017\end{array}$} \\
\hline $\begin{array}{l}\text { individual studies when interpreting/discussing the } \\
\text { results of the review? }\end{array}$ & yes & yes & no & yes & yes & yes & yes \\
\hline $\begin{array}{l}\text { (14) If meta-analysis was performed, did the review } \\
\text { authors assess the potential impact of RoB in } \\
\text { individual studies on the results of the meta-analysis } \\
\text { or other evidence synthesis? }\end{array}$ & yes & yes & NP & $\mathrm{NP}$ & NP & $\mathrm{NP}$ & $\mathrm{NP}$ \\
\hline $\begin{array}{l}\text { (15) If meta-analysis was justified, did the review } \\
\text { authors use appropriate methods for statistical } \\
\text { combination of results? }\end{array}$ & yes & yes & yes & NP & $\mathrm{NP}$ & NP & $\mathrm{NP}$ \\
\hline $\begin{array}{l}\text { (16) Did the review authors use a satisfactory } \\
\text { technique for assessing the risk of bias in individual } \\
\text { studies that were included in the review? }\end{array}$ & yes & yes & yes & yes & yes & yes & yes \\
\hline Total (yes) & 14 & 16 & 9 & 14 & 13 & 14 & 14 \\
\hline
\end{tabular}




\section{Discussion}

Several techniques and materials have been suggested for the alveolar ridge preservation after dental extraction and before implant placement. A recent review has investigated oral-derived mesenchymal stem cells (ODSC) and their value in bone regeneration for dental and maxillofacial surgeries [6]. However, mesenchymal stem cells (MSC) in regenerative medicine are still not applicable in the daily reconstructive surgery, even knowing that all mesenchymal stem cells from oral tissues are highly committed to differentiate towards osteoblasts and precursors of bone tissue, but may be a promising treatment in the future [5]. The controlled delivery of therapeutic substances by nanostructured biomaterials has been proposed as a viable approach to enhance the bone healing capacity, which ultimately results in the significant improvement of bone regeneration. This overview aimed to evaluate the methods, quality, and outcomes of previous systematic reviews conducted to investigate the effects of platelet-rich fibrin (PRF) in dental sockets of third molars.

This overview searched the systematic evidence for the effect of human alveolar socket preservation with PRF compared to spontaneous healing on dimensional alveolar changes, pain, bleeding, swelling, osteitis, and trismus. Only studies that evaluated PRF were evaluated and selected.

By aggregating only SR data, the present study was able to analyze the most conclusive scientific evidence. Among the SRs included, the selection of primary studies was very distinct. A complete search strategy is decisive in increasing the trustworthiness of results and decreasing the risk of bias. As PRF is a reservoir of cytokines, platelets, immune cells, and leukocytes, this characteristic led to the hypothesis that PRF could allow for a slow release of cytokines (transforming growth factor, platelet-derived growth factor, vascular endothelial growth factor, and epidermal growth factor), which play a critical role in angiogenesis and tissue healing [24].

From the 13 SRs evaluated, only four evaluated alveolar bone regeneration through meta-analysis. The results of two SRs concluded that PRF use did not significantly affect bone regeneration [20] (335 analyzed sockets). For osteoblastic activity [17] (935 analyzed sockets), however, two SRs [1,9] (756 analyzed sockets) observed positive results between the use of PRF and alveolar bone regeneration. Another five SRs [15,16,24-26] (1374 analyzed sockets) conducted qualitative analyzes (without meta-analysis) and also observed positive results of PRF concerning alveolar bone regeneration. The data shown by the SRs and analyzed by the present overview present a divergence of results, and do not allow for a definitive conclusion regarding the use of the isolated PRF for alveolar bone regeneration. Factors such as the type of treated socket (number of wall defects), surgical technique, and methodology for making the PRF directly influence the results and add possible bias to the conclusions.

Most SRs observed a significant reduction in pain in the sockets preserved with PRF. The simple fact of closing the entering of the socket with a membrane avoids food and debris entry, which can certainly decrease painful stimuli compared with an open socket [27]. Other hypotheses are the expression of immunological factors by supra-physiological living leukocytes release [16,28].

Blocking the entrance of the alveolus through the PRF membrane also helps stabilize the clot formed immediately after extraction. The fibrin mesh present in the PRF helps in the adherence and stability of the clot cells, which reduces bleeding as observed by the analyzed SRs $[14,17,20]$. In addition, the stabilization of the clot inside the alveolus is essential to prevent the occurrence of osteitis. The maintenance of clot biology associated with increased expression of immunological cells and cytokines may explain a lower number of osteitis when PRF was used [29].

Recent studies $[27,30]$ have also shown that alveoli filled with PRF membrane have accelerated soft tissue healing (epithelialization), especially in the first week, when compared to spontaneous healing.

\subsection{Study Strengths and Limitations/Implications for Clinical Practice}

This overview followed the PRISMA recommendations, including the development and prior registration of a protocol, an unrestricted search process (including grey literature), and a duplicate review process for the search, data extraction, and quality analysis. In addition, the outcome measures of the vast majority of SRs included in this overview $(n=71)$ were conducted by analyzing RCTs 
(the best evidence strength). However, this study is also subject to some limitations. First, some studies included in the SRs did not use the same protocol for making the PRF or did not present the centrifugation protocol. This can make it difficult to analyze and interpret the data. In addition, the quality analysis (AMSTAR 2) conducted demonstrated numerous methodological shortcomings in the performance of the SRs, which can increase the risk of bias.

\subsection{Recommendations for Further Research}

The analyzed SRs used different methodologies for making the PRF. The SRs included the following values for rotation per minute and time of centrifugation: $3000 \mathrm{rpm}$ for $10 \mathrm{~min}$ [1,14-18,20], $2030 \mathrm{rpm}$ for $10 \mathrm{~min}$ [14-17,20], $2700 \mathrm{rpm}$ for $12 \mathrm{~min}$ [1,15-18], 360-400 rpm for $20 \mathrm{~min}$ [1,9], $400 \mathrm{~g}$ for $10 \mathrm{~min}$ [31], and not reported [19,24,26]. It is important to note the wide variety of protocols used in these studies; however, all methods produced PRF, a clot composed of a dense fibrin mesh with a large presence of blood cells for the production of growth factors $[1,14-18,20,25]$. The current changes in the standards of measurement of the force exerted for the production of PRF should be taken into account. The authors of future works should refer to speed and time and the relative centrifugal force (RCF) applied during the centrifugation process. In addition, it should be reported at which point the blood collection tube will be calculated in the upper side (minimal RCF), the buffy coat/clot region (middle RCF), and at the end of the tube (maximum RCF). Moreover, size of the rotor (radius at the clot and end of the tube); rotor angulation for the tube holder; revolutions per minute and time; structure and size of tubes used to produce PRF; and centrifugation model utilized must also be considered. This standardization was recently proposed and is a way to reduce bias in studies with PRF [32,33].

Authors of future SRs are encouraged to follow the guidelines of the PRISMA checklist in order to improve the quality of the work.

\section{Conclusions}

After reviewing the available literature, and its due limitations, this overview can conclude that:

There is no definitive evidence for the effect of using PRF alone on bone regeneration in post-extraction sockets;

- The use of PRF improves soft tissue healing around the extraction socket;

- The use of PRF in post-extraction sockets significantly reduces postoperative pain;

- The use of PRF in post-extraction sockets decreases the level of postoperative bleeding;

- The use of PRF in post-extraction sockets reduces the number of osteitis occurrences;

- There is no evidence for the positive interrelation between PRF and the occurrence of trismus.

Author Contributions: Conceptualization, V.M., M.D.C.-M., C.F.d.A.B.M., and J.d.A.C.-M.; methodology, V.M., R.C.d.M.M.; software, V.M.; validation, M.D.C.-M., J.d.A.C.-M., K.J., and J.R.B.N.; formal analysis, V.M., A.C., P.M., and K.J.; investigation, V.M. and R.C.d.M.M.; resources, M.D.C-M.; data curation, V.M. and J.d.A.C.-M.; writing-original draft preparation, V.M., M.D.C.-M., C.F.d.A.B.M., R.C.d.M.M., and J.d.A.C.-M.; writing-review and editing, V.M., M.D.C.-M., C.F.d.A.B.M., and R.C.d.M.M.; visualization, J.R.B.N., K.J., A.C., P.M., and M.D.C.-M.; supervision, V.M., M.D.C.-M., and J.d.A.C.-M.; project administration; funding acquisition, A.C., P.M., and K.J. All authors have read and agreed to the published version of the manuscript.

Funding: This research was funded by Brazilian agencies Fundação de Amparo à Pesquisa do Estado do Rio de Janeiro-FAPERJ (grant number 202619/17 and 202620/17).

Conflicts of Interest: The authors declare no conflict of interest.

\section{References}

1. Del Fabbro, M.; Bucchi, C.; Lolato, A.; Corbella, S.; Testori, T.; Taschieri, S. Healing of Postextraction Sockets Preserved With Autologous Platelet Concentrates. A Systematic Review and Meta-Analysis. J. Oral Maxillofac Surg. 2017, 75, 1601-1615. [CrossRef] [PubMed] 
2. Del Fabbro, M.; Bortolin, M.; Taschieri, S. Is autologous platelet concentrate beneficial for post-extraction socket healing? A systematic review. Int. J. Oral Maxillofac Surg. 2011, 40, 891-900. [CrossRef] [PubMed]

3. Barone, A.; Ricci, M.; Tonelli, P.; Santini, S.; Covani, U. Tissue changes of extraction sockets in humans: A comparison of spontaneous healing vs. ridge preservation with secondary soft tissue healing. Clin. Oral Implants Res. 2013, 24, 1231-1237. [CrossRef] [PubMed]

4. Jahangiri, L.; Devlin, H.; Ting, K.; Nishimura, I. Current perspectives in residual ridge remodeling and its clinical implications: A review. J. Prosthet. Dent. 1998, 80, 224-237. [CrossRef]

5. Ballini, A.; Cantore, S.; Scacco, S.; Coletti, D.; Tatullo, M. Mesenchymal Stem Cells as Promoters, Enhancers, and Playmakers of the Translational Regenerative Medicine 2018. Stem Cells Int. 2018. [CrossRef]

6. Spagnuolo, G.; Codispoti, B.; Marrelli, M.; Rengo, C.; Rengo, S.; Tatullo, M. Commitment of Oral-Derived Stem Cells in Dental and Maxillofacial Applications. Dent. J. 2018, 6, 72. [CrossRef]

7. Marrazzo, P.; Paduano, F.; Palmieri, F.; Marrelli, M.; Tatullo, M. Highly Efficient In Vitro Reparative Behaviour of Dental Pulp Stem Cells Cultured with Standardised Platelet Lysate Supplementation. Stem Cells Int. 2016. [CrossRef]

8. Barry, M.; Pearce, H.; Cross, L.; Tatullo, M.; Gaharwar, A.K. Advances in Nanotechnology for the Treatment of Osteoporosis. Curr. Osteoporos 2016, 14, 87-94. [CrossRef]

9. Del Fabbro, M.; Corbella, S.; Taschieri, S.; Francetti, L.; Weinstein, R. Autologous platelet concentrate for post-extraction socket healing: A systematic review. Eur. J. Oral Implantol. 2014, 7, 333-344. [CrossRef]

10. Dohan, D.M.; Choukroun, J.; Diss, A.; Dohan, S.L.; Dohan, A.J.; Mouhyi, J.; Gogly, B. Platelet-rich fibrin (PRF): A second-generation platelet concentrate. Part I: Technological concepts and evolution. Oral Surg. Oral Med. Oral Pathol. Oral Radiol. 2006, 101, e37-e44. [CrossRef]

11. Dohan, D.M.; Choukroun, J.; Diss, A.; Dohan, S.L.; Dohan, A.J.; Mouhyi, J.; Gogly, B. Platelet-rich fibrin (PRF): A second-generation platelet concentrate. Part II: Platelet-related biologic features. Oral Surg. Oral Med. Oral Pathol. Oral Radiol. 2006, 101, e45-e50. [CrossRef] [PubMed]

12. Choukroun, J.; Diss, A.; Simonpieri, A.; Girard, M.O.; Schoeffler, C.; Dohan, S.L.; Dohan, A.J.; Mouhyi, J.; Dohan, D.M. Platelet-rich fibrin (PRF): A second-generation platelet concentrate. Part IV: Clinical effects on tissue healing. Oral Surg Oral Med. Oral Pathol Oral Radiol. 2006, 101, e56-e60. [CrossRef] [PubMed]

13. Naik, B.; Karunakar, P.; Jayadev, M.; Marshal, V.R. Role of Platelet rich fibrin in wound healing: A critical review. J. Conserv. Dent. 2013, 16, 284-293. [CrossRef] [PubMed]

14. Canellas, J.; Ritto, F.G.; Medeiros, P.J.D. Evaluation of postoperative complications after mandibular third molar surgery with the use of platelet-rich fibrin: A systematic review and meta-analysis. Int. J. Oral Maxillofac Surg. 2017, 46, 1138-1146. [CrossRef]

15. Canellas, J.; Medeiros, P.J.D.; Figueredo, C.; Fischer, R.G.; Ritto, F.G. Platelet-rich fibrin in oral surgical procedures: A systematic review and meta-analysis. Int. J. Oral Maxillofac Surg. 2019, 48, 395-414. [CrossRef]

16. Castro, A.B.; Herrero, E.R.; Slomka, V.; Pinto, N.; Teughels, W.; Quirynen, M. Antimicrobial capacity of Leucocyte-and Platelet Rich Fibrin against periodontal pathogens. Sci. Rep. 2019, 9, 8188. [CrossRef]

17. He, Y.; Chen, J.; Huang, Y.; Pan, Q.; Nie, M. Local Application of Platelet-Rich Fibrin During Lower Third Molar Extraction Improves Treatment Outcomes. J. Oral Maxillofac Surg. 2017, 75, 2497-2506. [CrossRef]

18. Moraschini, V.; Barboza, E.S. Effect of autologous platelet concentrates for alveolar socket preservation: A systematic review. Int. J. Oral Maxillofac Surg. 2015, 44, 632-641. [CrossRef]

19. Miron, R.J.; Zucchelli, G.; Pikos, M.A.; Salama, M.; Lee, S.; Guillemette, V.; Fujioka-Kobayashi, M.; Bishara, M.; Zhang, Y.; Wang, H.L.; et al. Use of platelet-rich fibrin in regenerative dentistry: A systematic review. Clin. Oral Investig. 2017, 21, 1913-1927. [CrossRef]

20. Al-Hamed, F.S.; Tawfik, M.A.; Abdelfadil, E.; Al-Saleh, M.A.Q. Efficacy of Platelet-Rich Fibrin After Mandibular Third Molar Extraction: A Systematic Review and Meta-Analysis. J. Oral Maxillofac Surg. 2017, 75, 1124-1135. [CrossRef]

21. Moher, D.; Liberati, A.; Tetzlaff, J.; Altman, D.G.; Group, P. Preferred reporting items for systematic reviews and meta-analyses: The PRISMA statement. J. Clin. Epidemiol. 2009, 62, 1006-1012. [CrossRef] [PubMed]

22. Schardt, C.; Adams, M.B.; Owens, T.; Keitz, S.; Fontelo, P. Utilization of the PICO framework to improve searching PubMed for clinical questions. BMC Med. Inform. Decis. Mak. 2007, 7, 16. [CrossRef] [PubMed]

23. Shea, B.J.; Reeves, B.C.; Wells, G.; Thuku, M.; Hamel, C.; Moran, J.; Moher, D.; Tugwell, P.; Welch, V.; Kristjansson, E.; et al. AMSTAR 2: A critical appraisal tool for systematic reviews that include randomised or non-randomised studies of healthcare interventions, or both. BMJ 2017, 358, j4008. [CrossRef] [PubMed] 
24. Balli, G.; Ioannou, A.; Powell, C.A.; Angelov, N.; Romanos, G.E.; Soldatos, N. Ridge Preservation Procedures after Tooth Extractions: A Systematic Review. Int. J. Dent. 2018, 2018, 8546568. [CrossRef] [PubMed]

25. Annunziata, M.; Guida, L.; Nastri, L.; Piccirillo, A.; Sommese, L.; Napoli, C. The Role of Autologous Platelet Concentrates in Alveolar Socket Preservation: A Systematic Review. Transfus. Med. Hemother. 2018, 45, 195-203. [CrossRef]

26. Niu, W.; Wang, P.; Ge, S.; Ji, P. Effects of Platelet Concentrates Used in Alveolar Ridge Preservation: A Systematic Review. Implant. Dent. 2018, 27, 498-506. [CrossRef]

27. de Almeida Barros Mourao, C.F.; de Mello-Machado, R.C.; Javid, K.; Moraschini, V. The use of leukocyte- and platelet-rich fibrin in the management of soft tissue healing and pain in post-extraction sockets: A randomized clinical trial. J. Craniomaxillofac Surg. 2020, 48, 452-457. [CrossRef]

28. Gassling, V.L.; Acil, Y.; Springer, I.N.; Hubert, N.; Wiltfang, J. Platelet-rich plasma and platelet-rich fibrin in human cell culture. Oral Surg. Oral Med. Oral Pathol. Oral Radiol. 2009, 108, 48-55. [CrossRef]

29. Bayer, A.; Lammel, J.; Rademacher, F.; Gross, J.; Siggelkow, M.; Lippross, S.; Kluter, T.; Varoga, D.; Tohidnezhad, M.; Pufe, T.; et al. Platelet-released growth factors induce the antimicrobial peptide human beta-defensin-2 in primary keratinocytes. Exp. Dermatol. 2016, 25, 460-465. [CrossRef]

30. Afat, I.M.; Akdogan, E.T.; Gonul, O. Effects of leukocyte- and platelet-rich fibrin alone and combined with hyaluronic acid on early soft tissue healing after surgical extraction of impacted mandibular third molars: A prospective clinical study. J. Craniomaxillofac Surg. 2019, 47, 280-286. [CrossRef]

31. Castro, A.B.; Meschi, N.; Temmerman, A.; Pinto, N.; Lambrechts, P.; Teughels, W.; Quirynen, M. Regenerative potential of leucocyte- and platelet-rich fibrin. Part B: Sinus floor elevation, alveolar ridge preservation and implant therapy. A systematic review. J. Clin. Periodontol. 2017, 44, 225-234. [CrossRef] [PubMed]

32. Miron, R.J.; Pinto, N.R.; Quirynen, M.; Ghanaati, S. Standardization of relative centrifugal forces in studies related to platelet-rich fibrin. J. Periodontol. 2019, 90, 817-820. [CrossRef] [PubMed]

33. Miron, R.J.; Choukroun, J.; Ghanaati, S. Reply from authors: RE: Optimized platelet-rich fibrin with the low-speed concept: Growth factor release, biocompatibility, and cellular response: Necessity for standardization of relative centrifugal force values in studies on platelet-rich fibrin. J. Periodontol. 2019, 90, 122-125. [CrossRef] [PubMed] 